811.163.41'373.7

821.163.41.08-84 Миливојевић, М. https://doi.org/10.18485/sj.2017.22.1.41

ДРАГАН В. ЛИЛИЋ

Универзитет у Приштини

Филозофски факултет Косовска Митровица
Оригинални научни рад

Примљен: 25. 06. 2016.

Прихваћен: 15. 12. 2016.

\title{
ФРАЗЕОЛОГИЗМИ „У АКЦИЈИ” У АФОРИЗМИМА МИЛЕНА МИЛИВОЈЕВИЋА
}

Наука о српском језику се све чешће, и верујемо успешно, са задатака нормативистике и дескрипције граматичких система окреће језику „у пракси”, и за предмет свога проучавања лакше него раније прихвата нестандардне облике (медијске коментаре, говор у породици, говор улице, жаргон, опсцену лексику...). У томе настојању и проучавања фразеологије (народнога говора као и уметничког текста) добијају на значају.

У раду се анализирају неки стилски поступци употребе фразеологизама у афоризмима у збиркама Ерогена прва лига и Премишљаји и домислице (из сељачког живота) афористичара Милена Миливојевића. Реч је о фразеолошким иновацијама, које између осталог обележава креативност, о феномену језика. у употреби. Иновације настале у „игри с фразеологијом” засноване су на реализацији семантичког потенцијала фразеологизама за које су у науци прихваћени термини дефразеологизација (буквализација) и алузија.

Кључне речи: фразеологизам, афоризам, игра с фразеологијом, фразеолошке иновације, дефразеологизација, алузија.

*draganlilic53@gmail.com 
Фразеологизам као лингвистички феномен чест је конститутивни елемент афоризма као литерарног феномена ${ }^{1}$. Али не само литерарног, односно уметничког, већ и филозофског, како тврди Фохт (1962: 14, према: Ковачевић 1995: 113): „Афоризам је јесте умјетнички облик, али није само умјетнички. Он је уједно и не у мањој мјери и филозофијски облик, тј. продукт једног посебног начина излагања филозофијских мисли - он је естетски свијет и естетски језик филозофије саме.” У том синтетичком књижевном жанру (с оствареном идеалном синтезом књижевности и филозофије), преко оног што је исказано, и како је исказано, откривамо оно што је мишљено. А тај атомски прозни израз најкраће могуће форме, обично од једне до две реченице, бременит је смислом. ${ }^{2}$

Уколико затражимо по речницима одредницу афоризам, најчешће ћемо наићи на објашњење да је то „кратка, језгровита, значењем богата изрека” Али и ширу дефиницију у литератури о њему: „Афоризам је несумњиво најкраћи жанр у прози или стиху (ретко) којим се духовито, на уметнички начин, изражава језгровито нека мисао о животу човека. Дакле, битна одређења афоризма су: језгровитост, мисаоност, духовитост и актуелност. Тематски је најчешће везан за политику, друштво, етику и филозофију, али и за друге области човековог стварања." (Животић 2004). Како је редовно критички интониран, дакле „сумњив жанр”, који настоји да разобличи друштвене аномалије и људску непромишљеност, оно што саопштава мора чинити на индиректан, скривен начин па стога он користи алузију, иронију, сарказам, контраст, хиперболу и алегорију, а нарочито двосмисленост, дилогију. ${ }^{3}$ Дефинисали су га и сами афористичари не себи својствен начин - афоризмом: „Афоризам је дриблинг духа на малом простору” (Баљак), „Афоризам - роман из кога су избачене сувишне речи" (Милован Илић Минимакс (1991: 119, према: Ковачевић 1999, 90). Идући за Станиславом Јежи Лецом, једног од највећег писаца сатиризама, истичући управо форму афоризма, један наш афористичар каже: „Реченица - највећа литерарна форма” (Сударски, 1989, према: Ковачевић 1999: 111).

${ }^{1}$ О улози фразеологизама у конституисању афористичког значења писала је Јасмина Вучетић (20012) анализирајући један број афоризама ексцерпираних са хумористичких страна дневног листа Јединство из Приштине (са тренутним седиштем у Београду и Грачаници). На основу анализе прикупљеног материјала издвојила је структурне типове афоризама с обзиром на структуру и експресивност фразеологизама унутар афоризма.

${ }^{2}$ Давно изречена сентенца En oligei leksei dinamis esti megale (У малом тексту велика снага) као одређење Хипократовог дела Афоризми истовремено је најсликовитија дефиниција, и данас употребљива, којом се истичу најбитније карактеристике овог жанра.

${ }^{3} \mathrm{O}$ дилогији као као фигури двосмислености у структури сатитризма - сатиричног афоризма в. у раду Дилогијска структура сатиризма (Ковачевић, 1995) 
У смислу назначеног предисловија, разматраћемо језички (што ће рећи и: стилски, фразеолошки) материјал који нам нуде две књиге афоризама Милена Миливојевића, ${ }^{4}$ песника и афористичара са занимљивим опусом, које су нам се наметнуле управо тиме да и једна и друга представљају тематске целине организоване од афоризама.

Збирка Ерогена прва лига, објављена је као награда на 13. међународном фестивалу афоризама и карикатуре 2012. године у Струмици, Македонија, паралелно на македонском и српском језику, с предговором Васила Толевског.

Збирка Премишљаји и досмислице, објављена је у серији Самовило, као резултат поетског осмишљавања живота и културе (оличнеих у језику) горштака Старе планине (источна Србија). Због тога се у њима као основна тема очитује однос сељака-горштака према животу, смрти, судбини, друштву. ${ }^{5}$

Афоризми Милена Миливојевића представљају врло веште и проницљиве духовне творевине инспирисане схватањима савременог човека, најчешће као одговори на изазове света и времена, и у њима, поред хуморне основе има и врло веште и благе сатиричне надградње.

Имају још једну одлику битну за нашу анализу, у њима се најчешће оваплоћује и оплођује занимљив конструктивни систем, који ће нам олакшати анализу.

${ }^{4}$ Милен Миливојевић (Драјинац код Сврљига 1943-), објавио је поезију: Pacnyћe (Caрајево, 1989), Тачка (Бор, 1989), Лажу вегетаријанции (Бор, 1991), Нећу више да се играм (Зајечар, 1966), Други колосек (Зајечар, 1999), Птиияа птииу птици (Бор, 2000), Год (Зајечар, 2003), Једносмерном траком (Пожега, 2005), Позор иште позориште (Бор, 2006), Суние у иепу (Београд, 2007), С врха језика (Ниш, 2011), Као кроз живот (Тузла, 2012); књигу сатиричне поезије: Царске песме (Бор, 2993); књиге афоризама: Ан пасан (Бор, 1992), Како сам постао уврнут (Зајечар, 1992), С ума (Бор, 1998), Није ово Данска (Бор, 2001), Гологлави Рајко и Црвенкапа (Бор 2002), Касно сам почео да пишем (Београд, 2008), Држави није добро (Београд, 2009), Ерогена прва лига (Струмица, 2013); књигу кратких сатиричних прича Носталгичне приче (Београд, 2004).

Заступљен је у антологијама афоризама „Враг и шала” и „Случајни узорак” Витомира Теофиловића, „Антологији балканског афоризма” Васила Толевског на македонском језику и у антологији антиратног афоризма Хасијера Агиреа „Пуцањ у рат” објаављеној у Шпанији на баскијском језику, као и у више тематских зборника, прегледа, панорама и лексикона афоризама.

Добитник је златне плакете за афоризме на 13. и 15. међународном фестивалу еротског афоризма и карикатуре за 2012. и 2014. годину у Струмици (Македонија).

Члан је Удружења књижевника Србије. Живи у Бору.

${ }^{5}$ Издавач Хемимонтана окупља истраживаче културнох и језичког наслеђа Старе планине и ради под руководством проф. Недељка Богдановића. У серији Самовило, поред књиге Милена Миливојевића објављене су и књиге: Врвина за нево (Зоран Вучић), Венаи твориу и друге песме (Обрен Ристић), Јагње Ђурђевско (др Драгољуб Симоновић), Олтар у планини (др Недељко Богдановић). 
У употреби фразеологизама у афоризмима које намеравамо да анализирамо уочавамо неке структурне поступке које имају последице на семантичком плану. Неки лингвисти такву употребу у фразеологији називају „игром с фразеологијом". Афористичар је игралачка особа чији исказ удара оштро, снажно попут staccata (Brozović 2012: 48). Та игра онеобичава афоризам, и практично представља разарење фразема на структурном плану. Овај поступак имамо и код нашег афористичара.

Фразеологизам „набити коме рогове” (преварити брачног друга) искоришћен је у већем броју ауторових афоризама:

(1) Шта ли је нашла на њему кад и он има рогове као и ја?! Замисли се во, гледајући бика. М1 53;

(2) Најкрући делови код превареног мужа су рогови. M1 48;

(3) Помирио сам се са роговима, са женом још нисам. M1 50;

(4) Во се веже за рогове, а рогоња за неверну жену. М1 53.

Овај поступак можемо да назовемо алузијом. Он се састоји у томе што се фразем разграђује изостављањем више његових компонената, а задржавањем једне, на коју се своди комплексност фразеолошке семантике. У дескриптивном смислу: „преварени је добио рогове”, постао је „рогоња”.

Дилогија, односно двосмисленост, остварује се у афоризмима, где имамо поигравање са фразеолошким и нефразеолошким значењем:

(5) У сваком житу има кукоља. Али то је проблем оних који имају жито. M2 20.

(6) Код нас се ништа не ради испод жита. Није родило. М2 20.

(7) Цветају нам руже. Најбоље се то види по букетима на гробовима. M2 24.

У наведеним примерима амбигвалност се постиже могућношћу двоструког тумачења фразеологизма (Ковачевић 1999: 117).

У примеру (6) - у првој реченици видимо фразеологизам „радити што испод жита”, са значењем „радити нешто скривено, трајно, подмукло”. Са таквим га значењем прихвата читалац. То се фразеолошко значење поништава другим исказом, који гласи - није родило. Оваква игра производи хумор који се заснива на неподударности, односно на сукобу између афористичаревог исказа и читаочевог очекивања. Могућност двоструког тумачења фразеологизама омогућава афористичару овакво поигравање с читаоцем. 
У примеру (7) осим хуморности до изражаја долази и појачана сатиричност, као осуда стања нечег негативног. Најпре имамо фразеологизам „цветају коме руже” чије је значење „успешност у животу и у раду”.Такво значење читалац ишчитава из првог дела афоризма (Цветају нам руже.). Међутим, то фразеолошко значење се поништава другим делом (Најбоље се то види по букетима на гробовима.). Сатиричност се рађа из нове слике - цвећа на гробовима! Горка истина о нашем стању саопштава се на основу могућности двоструког тумачења фразеологизма.

Још једна карактеристика употребе фразеологизама код М. Миливојевића, огледа се у употреби два фразеологизма у једном афоризму:

(8) Ситна боранија је мања од маковог зрна. М2 10.

(9) Сељацима обећавају брда и долине а грађанима куле и градове. М2 13.

(10) Према људским сузама крокодилске сузе су лук и вода. М2 47.

Сваки од наведених примера афоризама има по два, очигледна, фразеологизма. У примеру (8) то су: „ситна боранија” („,безначајни људи, неважна особа”) и „бити мањи од маковог зрна” (,безначјно, ситно”). У примеру (9) то cy: „обећавати коме брда и долине” (,обећавати много, лажно, претерано, зеб могућности за извршење”, и „обећавати куле и градове”, са истим значењем. У примеру (10)" лити крокодилске сузе” (,,лажно изражавање жалости, неискрено жалити” и: „лук и вода је што” („не значити ништа, бити безначајно, безвредно што").

За ауторов стваралачки поступак, чини се, занимљив је још један модел, који видимо у примеру:

(11) У вучјем свету модни хит је јагњећа кожа. М2 30.

У овом афоризму осећа се транформисаност фразеологизма вук у јагњећој кожи (,лажна, улепшана слика суровог карактера”). Дескрипција целог афоризма, захваљујући управо имплицираном фразеологизму у његовом саставу, могла би се схватити и овако: Данас (хит!), у свету у коме живимо, најбоље пролазе људи који су окарактерисани фразеолошким значењем „бити вук у јагњећој кожи".

За разлику од афоризама који „се отварају” фразеологизмом има и примера где је поента исказана фразеологизмом у другом делу:

(12) Дабоме да нам пада наталитет, кад час-час, па због нечега, уместо деце, рађамо мечку. (М1 66).

Фразеологизам „рађати мечку” („бити у великим невољама”) затвара афоризам. За сатиричност / хумористичност овог афоризма искоришћен је 
фразеологизам. Из фразеологизма оскоришћена је десемантизвана компонента „рађати” која је омогућила конситуисање наведеног афоризма (наталитет пада - нерађањем деце!).

Чињеница да је М1 књига афоризама који су преведени на други језик (овде македонски), а с обзиром да су фраземи ,јединице устаљене структуре” (која подразумева устаљено значење + устаљена форма), поставља питања преводивости афоризама односно функционисање афоризама у различитим контекстима. Рецимо фразем ,лежати на срцу” подједнако је успешан на оба (преводом заступљена) културна подручја (српски : македонски): Супруга ми лежи на срцу. Уместо да нешто ради; према (прев.): Жената ми лежи на срие. Наместо нешто да работи. М1 33. ${ }^{6}$ Књига пред нама пружа прилику и за таква проучавања, а основни наш утисак је да вероватно због блискости српске и македонске културе на фразеолошком плану има велике подударности, али да се на плану синтаксе два језика могу наћи адекватне паралеле:

а) према: Не могу да верујем својим очима - заљубио сам се на први поглед!, на српском, стоји:

б) Не можам да им верувам на своите очи - се заљубив на прв поглед! $(\mathrm{M} 1,17)$, где се поред балканистичке конструкције на своите очи : својим очима, јавља и аорист (се заљубив) према перфекту (заљубио сам се), а јавља се и удвајање објекта - што је особина македонског (им - на свочте очи), према: својим очима, како је у српском стандардном језику. Таква анализа стилистички релевантних паралела била би свакако занимљива, али то остаје за другу прилику.

Дилогијски тип афоризама-сатиризама подразумева у једном сегменту елементе асоцијативног поља, које омогућава повезивање са контекстом. Ако је тај контекст историјска и друштвена стварност, афоризам има културолошку сврху, јер повезује предзнање (предтекст) са ситуацијом која се афоризмом конституише. На тај начин он је комуникациони (што ће рећи сематнички и формални) посредник између искуства и пројекције. Аутори таквих афоризама имају заслуге што се читаочев доживљај формира на чврстој бази појмовних

\footnotetext{
${ }^{6}$ Остављамо по страни могућност коментара односа супруга : жена, јер је и у српском могућа употреба речи „жена” у наведеном контексту, као што не би ни мак. било страно „сапруга”. Варијације су вероватно успостављене с разлогом, који овом приликом занемарујемо.
} 
односа једне културе (народа, места, времена) и генерација које на поимању стварности коју нуди афоризам треба да конституишу сопствену стварност, са својим системом вредности, управо другачијом од оне коју афоризам „напада”.

\section{ИЗВОРИ}

M1: Милен Миливојевић: Ерогена прва лига (паралелно издање на српском и македонском језику; Центар за културу „Антон Панов”, Струмица.

М2: Милен Миливојевић: Премииљаји и досмислице из сељачког живота, Хемимонтана, Ниш.

\section{ЛИТЕРАТУРА}

Баришић 2011: Милина Ивановић Баришић: Сведочанство времена - афоризам; у: Гласник Етнографског института САНУ LIX (2), стр. 171-179.

Вучетић 2012: Јасмина Вучетић: Фразеологизам као стожер афористичког мишљења и казивања; у: Баштина, Приштина - Лепосавић, бр. 32, стр.75-85.

Дидковская 2012: Виктория Дидковская: Фразеологизам как «учасник» языковой игри в текстах современной литератури, у: Учені записки Таврійского національного університету ім. В. І. Вернадського. Серия Філологія Соиіальні комунікаиії. - 2012 -Т. 25 (64), № 2 (1) . - C. $180-186$.

Ковачевић 1995: Милош Ковачевић: Стилистика и граматика стилских фигура ${ }^{2}$, Унирекс, Никшић.

Кржишник 2012: Эрика Кржишник: Два аспекта семантического потенциала Фраземы; у: Учені записки Таврійського начіонального університету ім. В. І. Вернадського. Серия Філологія Соціальні комунікації. - 2012 -Т. 25 (64), № 2 (1) . - С. 134-140.

Лебедева 2012: Лебедева Людмила: Игровая вариативность устойчивых сравнений и поле нормативност, у: Учені записки Таврійского національного університету ім. В. І. Вернадського. Серия Філологія Соціальні комунікащиї. - 2012 -Т. 25 (64), No 2 (1) . - С. 94-99.

Фохт 1962: Унутарњи механизам афоризма, Израз, VI/7, Sarajevo, 1962. 
Brozović 2012: Domagoj Brozović: Od ironije do aforizma, u: Umjetnost riječi (LVI (2012), Zagreb.

Fink 2012: Željka Fink: Šta nam srce kaže? (Od reklamnog slogana do frazeosheme), u: Учені записки Таврійского наиіонального університету ім. В. I. Вернадського. Серия Філологія Соціальні комунікаиії. - 2012 -T. 25 (64), № 2 (1) . - C. 134-140.

Kovačević 2012: Barbara Kovačević: Frazeološke modifikacije u novinskim naslovima, u: Учені записки Таврійського національного університету ім. В. І. Вернадського. Серия Філологія Соціальні комунікаиії. - 2012 -Т. 25 (64), № 2 (1) . - С. 141-145.

Marković 2013: Bojana Marković: Kreativna upotreba frazema i drugih višerječnica u djelima Mladena Kerstnera - mogućnosti i namjere, u: Jezikoslovlje, 14-1 (2003): 129-159.

Pintarić 2009: Anita Pintarić: Modifikacija frazema u hrvatskom i njemačkom jeziku, u: Jezikoslovlje, 10.1. (2009), Zagreb, стр. 59-72.

Vasung 2012: Ana Vasung: Frazemi s varijabilnom numeričkom sastavnicom u bugarskom i hrvatskom jeziku; u: Учені записки Таврійського національного університету ім. В. І. Вернадського. Серия Філологія Сочіальні комунікачіï. - 2012 -Т. 25 (64), № 2 (1) . - С. 153-158.

Životić 2004: Radomir Životić: Njegovo veličanstvo aforizam, u: ETNA - časopis za satiru, br. 42, Beograd, str. 7-8.

\section{ВЕБОГРАФИЈА}

\section{Извори интернет-информација}

Simić Aforizam: Slobodan Simić: Aforizam - od medicine do satire, u: http://www. jovonikolic.com/aforizam-na-simpozijumu < 8. 5. 2016.

Denčić Aforizam: Šta je aforizam? Smeh do bola; u: http://aforizmi.org/zašto/štaje-aforizam <21. 1. 2016. 


\section{PHRASEOLOGISMS „IN ACTION” IN THE APHORISMS OF MILEN MILIVOJEVIĆ}

\section{Summary}

In contemporary culture, there is a growing number of books of aphorisms that reflect a kind of linguistic creativity beyond the ordinary boundaires of meaning of literature, but also a growing number of scientific papers on the various aspects of aphorisms and phraseologisms.

In this paper, Phraseologisms ,, in action” in the aphorisms of Milen Milivojević, we analyze materials based of two author's books, pointing briefly at the existence of several types of semantic and structural aphorisms, whose performance is based on the existence, the functions, transformations and intensification of meanings utilized in the formation of aphorisms.

Keywords: phraseologisms, aphorisms, word games, innovation, dephraseologization, allusiveness.

Dragan V. Lilić 